\title{
Pembahasan soal tes potensi skolastik pada SBMPTN 2020 untuk meningkatkan kualitas pelayanan online di tengah pandemi Covid-19 di bimbel dan privat MATRIKS
}

\author{
Vivi Iswanti Nursyirwan ${ }^{1^{*}}$; Nina Valentika ${ }^{2}$; Choirul Basir ${ }^{2}$; Gerry Sastro ${ }^{2}$;lmadi ${ }^{2}$ \\ 1 Jurusan S1 Akuntansi, Fakultas Ekonomi, Universitas Pamulang, Tangerang Selatan, Indonesia \\ 2 Jurusan Matematika, Fakultas Matematika dan Ilmu Pengetahuan Alam, Universitas Pamulang, \\ Tangerang Selatan, Indonesia
}

\begin{abstract}
Email: dosen02226@unpam.ac.id ${ }^{1} ;$ dosen02339@unpam.ac.id²; dosen02278@unpam.ac.id²; dosen00544@unpam.ac.id ${ }^{2}$; dosen01926@unpam.ac.id ${ }^{2}$
\end{abstract}

\begin{abstract}
Abstrak. Tujuan pengabdian masyarakat yang dilaksanakan oleh Tim Dosen Universitas Pamulang ini adalah memberikan solusi dalam menjawab soal tes potensi skolastik kepada para siswa SMU kelas XII sebagai upaya menyiapkan diri mengikuti seleksi bersama masuk perguruan tinggi negeri (SBMPTN) 2020. Mitra pengabdian masyarakat ini adalah bimbingan belajar dan privat MATRIKS di wilayah Pamulang, Tangerang Selatan, Banten. Subjek pengabdian masyarakat yakni para siswa dibangku sekolah menengah umum kelas XII yang berkeinginan untuk masuk perguruan tinggi negeri melalui tes SBMPTN 2020. Masalah utama yang dihadapi mitra adalah selama ini media pembelajaran Bimbel selalu secara tatap muka dan tidak pernah melakukan media pembelajaran secara daring, hal ini dikarenakan secara teknologi bimbel dan privat MATRIKS belum support dalam menyediakan layanan tersebut. Solusi yang ditawarkan adalah melakukan pembelajaran secara daring menggunakan aplikasi online meeting. Manfaat langsung dari kegiatan pengabdian ini adalah sebagai tambahan pengetahuan, keterampilan dalam menyelesaikan soal-soal potensi skolastik sehingga siswa dapat mempersiapkan seleksi bersama masuk perguruan tinggi negeri 2020 dengan metode penyelesaiaan soal secara cepat dan mudah. Manfaat turunan diharapkan, dapat menjadikan para siswa lolos SBMPTN 2020. Kegiatan pengabdian kepada masyarakat ini dilakukan dalam bentuk pelatihan dengan pemberian materi dan praktik menyelesaikan soal-soal ujian SBMPTN 2020. Pelatihan diselenggarakan selama dua pekan, yakni pada hari senin-jum'at, 11 mei- 15 mei 2020 dan senin-jum'at, 18-22 mei 2020. Metode kegiatan yang digunakan yakni ceramah, praktik, tanya jawab dan diskusi. Teknik analisis dilakukan dengan observasi aspek kognisi dan keterampilan siswa dalam menaklukan soal-soal bahasan.
\end{abstract}

Kata kunci: Pembahasan Soal, Tes Potensi Skolastik, SBMPTN

Abstract: The purpose of community service carried out by the Pamulang University lecturer Team is to provide discussion assistance in answering questions about scholastic potential test to class XII high school students in preparing themselves to take part in the joint selection of state universities (SBMPTN) 2020. Partners in this community service are tutoring and private matrices in Pamulang, South Tangerang, Banten. The subject of community service is students in the public high school class XII who wish to enter state higher education through the SBMPTN 2020 test. The main problem faced by partners is that up to now Bimbel learning media has always been face to face and have never done online learning media, this because technologically Bimbel and private matrix not yet support in providing these services. The solution offered is to do online learning by online meeting application. The direct benefit of this dedication activity is an additional knowledge, skills in solving potential scholastic questions so that students can prepare for the joint selection of 2020 state universities with the method of solving problems quickly and easily. The derivate benefits are expected to be able to make students pass the SBMPTN 2020. This community service activity is carried out in the form of training by providing material and practice of 
completing the 2020 SBMPTN exam questions. The training is held for two weeks, namely in Monday to Friday, 11 -15 May 2020, and 18-22 May 2020. The method of activities used are practices, questions and answers and discussions. The analysis technique is done by observing aspects of student's cognition and skills in conquering the subject matter.

Keywords: Problem Discussion, Scholastic Potential Test, SBMPTN 2020

\section{Pendahuluan}

MATRIKS merupakan sebuah lembaga bimbingan belajar dan privat dengan pasar sasaran adalah para siswa dari tingkat pendidikan SD-SMU. Sebagaimana kita ketahui bahwa kondisi pandemi covid 19 sudah kita rasakan sejak awal tahun 2020. Problematika ditengah kondisi pandemi covid 19 juga dirasakan oleh bimbingan belajar MATRIKS. Usaha pada sektor pendidikan ini mendapat tantangan tersendiri dalam berperan aktif menjalankan nilai-nilai luhur amanat pembukaan UndangUndang Dasar 1945 pada alinea ke 4, yakni upaya mencerdaskan kehidupan bangsa.

Pandemi korona virus di Indonesia merupakan bagian dari pandemi penyakit korona virus (Covid) 19 yang sedang berlangsung di seluruh dunia. Sebagai tanggapan terhadap pandemi, beberapa wilayah telah memberlakukan pemberlakuan sosial berskala besar (PSBB). Pemerintah Republik Indonesia sudah memberikan arahan untuk melakukan pembelajaran secara daring sebagai upaya tetap menumbuhkembangkan kegiatan belajar bagi anak bangsa. Begitu pula dengan MATRIKS, sebagai lembaga bimbingan belajar, MATRIKS mengalami kendala dalam menjalankan peran sebagai lembaga kegiatan bimbingan belajar dan privat dalam mendeliverykan kegiatan pengajaran di masa seperti ini. MATRIKS merasa kesulitan dalam menyampaikan metode pembelajaran yang efektif dan efisien khususnya bagi siswa XII yang ingin mengikuti seleksi bersama masuk perguruan tinggi negeri pada tahun 2020. MATRIKS saat ini sedang memformulasikan metode e-learning. Namun dibutuhkan waktu dan development serta infrastruktur teknologi yang cukup mumpuni dalam menghadirkan layanan tersebut jika harus dieksekusi sesegera mungkin, ini menjadi tantangan tersendiri bagi MATRIKS.

Dalam penelitian Fan dan Fang (2006) menyatakan bahwa variabel kualitas informasi dan kualitas sistem memiliki hubungan/pengaruh dengan variabel penggunaan. Diharapkan kegiatan pengabdian masyarakat ini dapat memberikan kepuasan pengguna (user satisfaction) melalui pembelajaran berbasis daring dengan pemanfaatan online meeting application.

Berdasarkan situasi tersebut, kami para Dosen Universitas Pamulang memiliki inisiasi untuk melaksanakan pengabdian kepada masyarakat bersinergi dengan mitra MATRIKS. Tujuan pengabdian masyarakat ini adalah bagaimana kami para Dosen Universitas Pamulang dapat membantu mitra dalam menyelenggarakan kegiatan pembelajaran berbasis daring, namun tetap dapat memberikan kualitas pembelajaran sebagaimana tagline dari lembaga MATRIKS itu sendiri yakni "Prestasi Tinggi dimulai Dari Sini" .

Kami para Dosen Universitas Pamulang merasa terpanggil untuk secara konkret membantu memastikan kontinuitas dunia pendidikan dalam membantu masyarakat dalam menggapai cita.

\section{Tinjauan Teori}

\section{Pengertian dan Definisi Test Potensi Skolastik}


Sebagaimana dilansir oleh kompas.com Tes Potensi Scholastik adalah salah satu jenis tes yang mengukur kemampuan kognitif, yaitu kemampuan penalaran dan pemahaman umum yang penting untuk keberhasilan di sekolah formal, khususnya pendidikan tinggi. Kemampuan ini meliputi kemampuan penalaran umum, pengetahuan kuantitatif, pengetahuan dan pemahaman umum, serta kemampuan memahami bacaan dan menulis.

\section{Pengertian E-Learning}

E-Learning adalah proses pembelajaran berbasis elektronik. Salah satu media yang digunakan adalah jaringan komputer. Dengan dikembangkannya di jaringan komputer memungkinkan untuk dikembangkan dalam bentuk berbasis web, sehingga kemudian dikembangkan ke jaringan komputer yang lebih luas yaitu internet. Penyajian e -learning berbasis web ini bisa menjadi lebih interaktif.

Menurut (Michael, 2013:27) e-learning adalah pembelajaran yang disusun dengan tujuan menggunakan suatu sistem elektronik atau juga komputer sehingga mampu mendukung suatu proses pembelajaran. Menurut Chandrawati (2010), e learning adalah suatu proses pembelajaran jarak jauh dengan cara menggabungkan prinsip-prinsip didalam proses suatu pembelajaran dengan teknologi.

Surjono (2010:6) menyatakan bahwa pembelajaran hybrid learning atau blended learning adalah pembelajaran yang menggabungkan semua bentuk pembelajaran misalnya online, live, maupun tatap muka (konvensional).

\section{Pengertian Blended E-Learning}

Menurut Carmen (2005), blended learning adalah setiap saat siswa dapat belajar, sebagian belajar dengan tatap muka dan sebagian dengan bantuan internet. Model belajar blended learning bertujuan untuk mendapatkan pembelajaran yang paling baik dengan menggabungkan berbagai keunggulan masing-masing komponen metode konvensional dan komponen online (Husamah, 2014). Adapun unsur-unsur yang harus ada dalam metode belajar blended learning adalah tatap muka, belajar mandiri, aplikasi, tutorial, kerjasama dan evaluasi.

\section{Metode}

Berdasarkan analisis situasi bersama dengan mitra kegiatan, pelaksanaan kegiatan pengabdian masyarakat ini dilakukan secara virtual. Menggunakan "online meeting application", zoom. Kegiatan dilaksanakan selama 2 pekan, yakni pada tanggal 11-15 Mei 2020 dan 18-22 Mei 2020. Kegiatan ini berlangsung pada pukul 14.45- 17.30. Kegiatan mengusung tema acara: Pembahasan Soal Tes Potensi Skolastik SBMPTN 2020, dengan peserta merupakan para siswa/i bimbingan belajar MATRIKS jenjang 12 SMA dan partisipan umum lainnya. Kegiatan pembahasan soal tes potensi skolastik dilakukan dengan metode ceramah, diskusi, praktik menyelesaikan soal disertai tips dan trik penyelesaiannya, dan dan tanya jawab. 


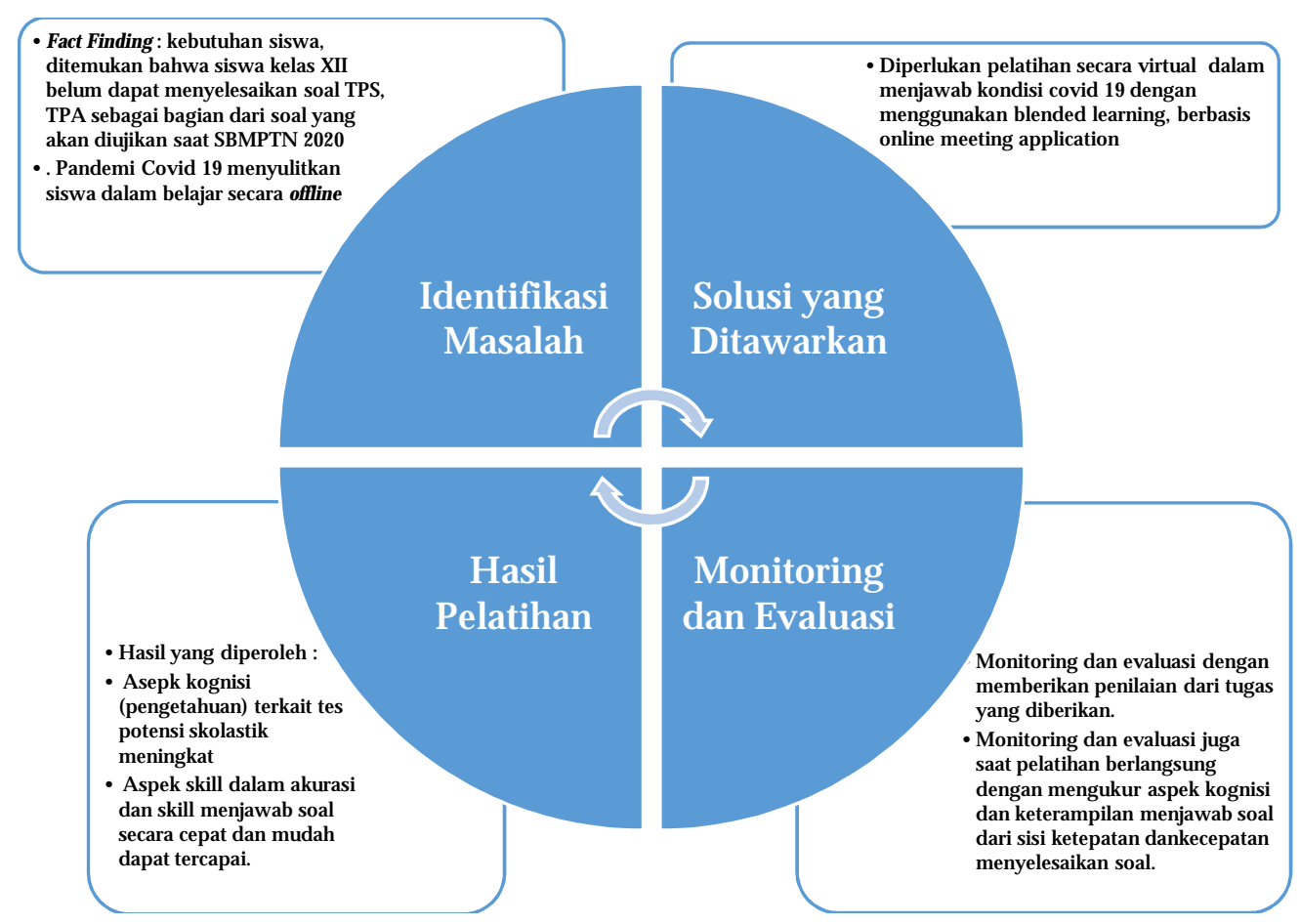

Gambar 1. Metode Kegiatan Pengabdian kepada Masyarakat

\section{Hasil dan Pembahasan}

Kegiatan pengabdian kepada masyakat yang dilakukan oleh para Dosen Universitas Pamulang berupa pemberian materi berupa ceramah, praktik menjawab soal-soal tes potensi skolastik, pembahasan, diskusi dan tanya jawab. Kegiatan berlangsung selama 2 pekan pada bulan Ramadhan, yakni pada tanggal 11 Mei 2020-15 Mei 2020 dan 18Mei-22 Mei 2020. Partisipan kegiatan yakni para siswa SMU kelas XII dan juga para mahasiswa Universitas Pamulang. Menyadari perlunya intensitas dalam membahas tes potensi skolastik, kegiatan pengabdian masyarakat ini dijalankan selama 2 pekan, dengan melibatkan 5 mahasiswa Universitas Pamulang, diantaranya : Ambang Jelang Hari (semester 6), Chitra Arisila Putri (semester 6), Asep Anjasmara Laxmana (semester 4), Farhan Anfasal Muluk (semester 6), Askolani (semester 6). Metode pembahasan soal dengan berfokus pada pemberian berbagai jenis soal tes potensi skolastik, dan memberikan metode penyelesaian soal secara cepat dan tepat, sehingga siswa memiliki keterampilan dalam mengenal berbagai soal dan memahami metode penyelesaian soal secara cepat dan tepat guna. Pemberian materi dilakukan oleh Bapak Choirul Basir, S.Si.,M.Si dosen Universitas Pamulang dari Program Studi Matematika. Beberapa Dosen lainnya seperti Ibu Vivi Iswanti Nursyirwan, S.Sos.,M.M, Ibu Nina Valentika, S.Si, M.Si, Bpk. Gerry Sastro, S.Si, M.Pd, Bpk. Ilmadi, M.Pd melakukan observasi para siswa dalam penyelesaian soal tes potensi skolastik dan melakukan pemberian nilai. Selama acara berlangsung siswa sangat antusias dalam menyelesaikan soal dan memerhatikan metode penyelesaian soal dengan sangat fokus. 


\section{Kesimpulan}

Berdasarkan hasil observasi, wawancara dan penilaian tim dosen atas kegiatan pengabdian masyarakat yang berlangsung selama 2 pekan ini, kegiatan pengabdian berlangsung sangat baik dan lancar. Pembelajaran berbasis virtual menggunakan online meeting application ditengah kondisi pandemi covid 19 dapat menjadi solusi dalam membantu siswa menyelesaikan soal tes potensi skolastik.

\section{Ucapan Terimakasih}

Penulis mengucapkan terimakasih kepada Lembaga Penelitian dan Pengabdian Masyarakat Universitas Pamulang atas support dan dukungannya sehingga kegiatan pengabdian masyarakat ini dapat berjalan dengan baik. Kami juga mengucapkan terimakasih kepada mitra bimbingan belajar MATRIKS dan privat atas support dan dukungan, sehingga bisa bermitra dan berbagi ilmu serta bersinergi dalam membantu masyarakat sekitar khususnya dari sisi edukasi. Terimakasih pula kepada Rektor, Ketua Prodi Akuntansi S1 dan Ketua Prodi Matematika.

\section{Daftar Pustaka}

Allen, Michael. 2013. Michael Allen's Guide to e-learning. Canada: John Wiley \& Sons.

Carmen, J. M. 2005. Blended Learning Design: Five Key Ingredients. Retrieved February 13, 2018.

Chandrawati, Sri Rahayu. 2010. Pemanfaatan e-learning dalam Pembelajaran. No 2 Vol. 8.

Fan, Jeff C., Fang, Kwoting. 2006. ERP Implementation and Information System Success: A Test of DeLone and McLean's Model. PICMET: 1272-1278.

Husamah. 2014. Pembelajaran Baruan (Blended Learning). Malang: Prestasi Pustaka.

https://edukasi.kompas.com/read/2020/01/08/15073061/mengenal-materi-utbk-2020-syarat-wajib-sbmptn?page=all

Surjono, Herman Dwi. (2010). Membangun Course E-Learning Berbasis Moodle. Yogyakarta: Universitas Negeri Yogyakarta 


\section{Lampiran}

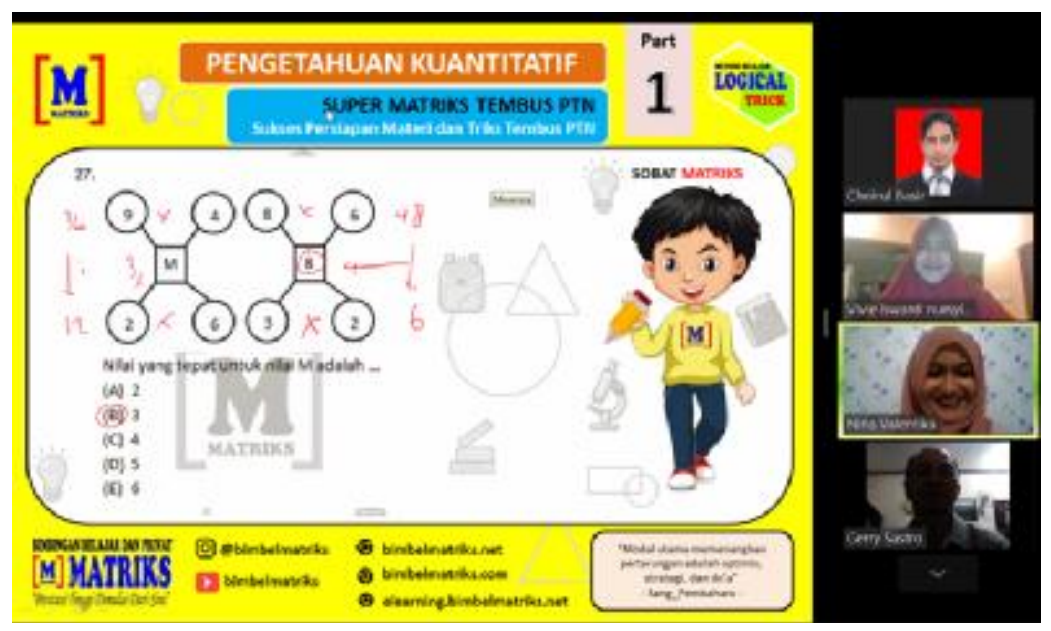

Contoh soal pembahasan soal tes potensi scholastik

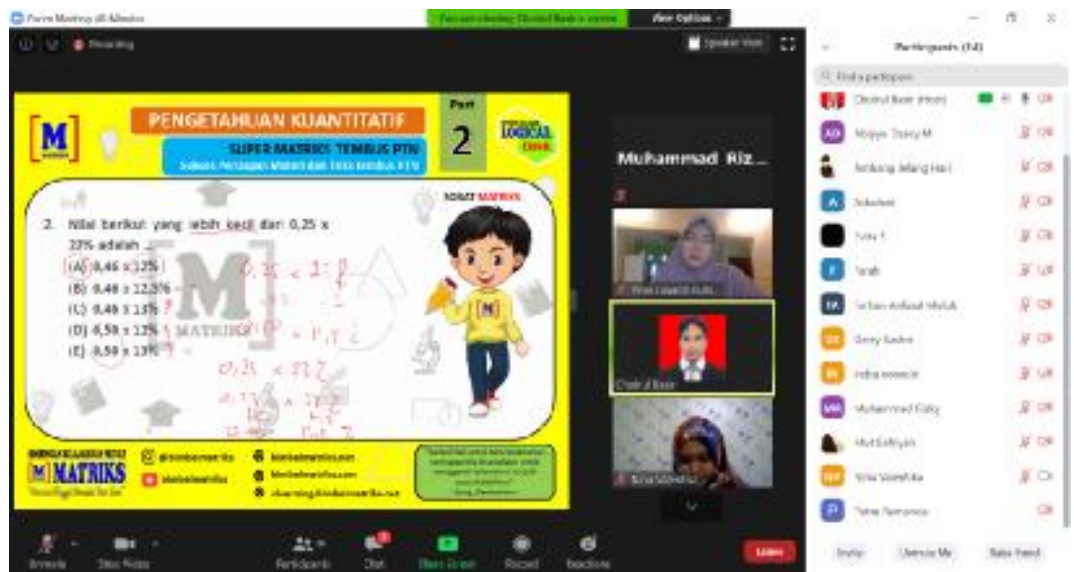

Contoh soal pembahasan tes potensi scholastik

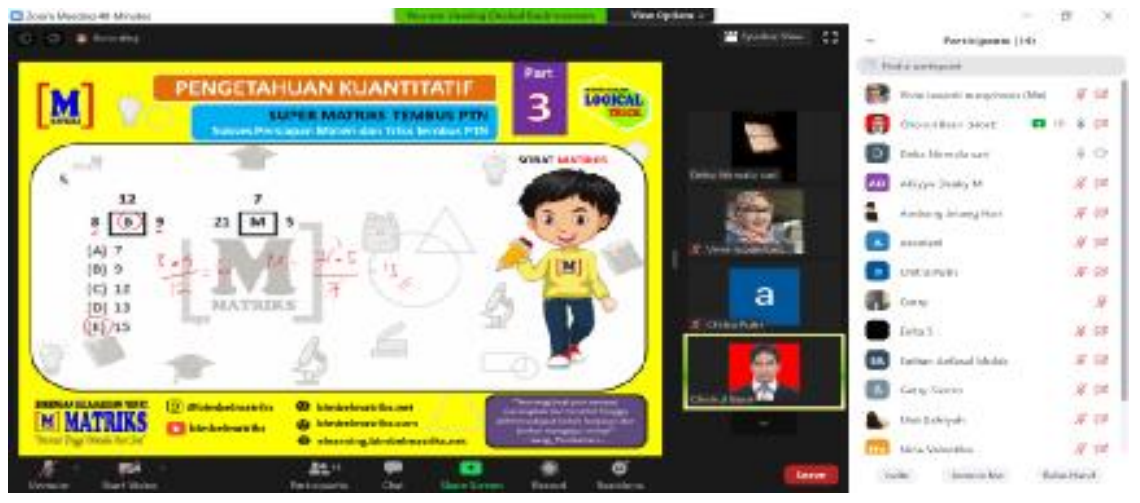

Contoh soal pembahasan tes potensi scholastik 